Reprod. Nutr. Dévelop., 1983, 23 (6), 967-977.

\title{
Circadian changes in the abomasal secretions of the preruminant calf
}

\author{
P. GUILLOTEAU, R. TOULLEC
}

with the technical assistance of Marguerite BEAUFILS, S. BOUSSION, H. FLAGEUL, Monique LESNE and Y. MANIS

Station de Recherches sur les Jeunes Bovins, I.N.R.A., 65, rue de St-Brieuc, 35042 Rennes Cedex, France.

Summary. The purpose of this study was to investigate the circadian changes in the abomasal secretions (quantities of juice, enzymes and electrolytes) of the preruminant calf. The gastric juice was collected every hour from five calves fitted with an innervated abomasal pouch and given milk twice daily, with a 7-h interval between the morning and the evening meals.

The amounts of gastric secretions produced were steady during $24 \mathrm{~h}$, except for changes after the meals. The morning meal caused a considerable increase in secretions of electrolytes and enzymes. The values of $\mathrm{Cl}^{-}, \mathrm{H}^{+}, \mathrm{Na}^{+}$and $\mathrm{K}^{+}$ions, chymosin and pepsin in the first postprandial hour were $3.8,4.1,3.5,2.6,2.4$ and 2.1 times higher, respectively, than those of the 24th hour used as prefeeding levels. The influence of the evening meal on secretions of $\mathrm{Cl}^{-}$and $\mathrm{Na}^{+}$ions and enzymes was less marked and also more delayed for all electrolytes. Variations in the amounts secreted per hour appeared to be greater for $\mathrm{H}^{+}$ ions than for enzymes, thus the ratios between maximal and minimal quantities observed during the 24-h cycle were 4.6 for $\mathrm{H}^{+}$ions and 2.8 for chymosin.

\section{Introduction.}

The abomasum of the calf corresponds to the stomach of monogastric animals ; in fact, it is the only functional gastric reservoir in the preruminant animal. Milk is ingested during short-lasting meals (usually less than 3 min in the bucket-fed-calf). The abomasum not only serves as a reservoir, but it also participates in digestion (Guilloteau et al., 1981) and therefore its secretions adapt to meal frequency. Furthermore, it may be assumed that this organ, like the pancreas, possesses its own secretory rhythm independent of feeding (Davicco, 1978). To our knowledge, the effect of a meal on the secretion of certain gastric juice components has only been studied over some hours (Ash, 1964; Hill, Noakes and Lowe, 1970 ; Rusev, Petrov and Bocheva, 1971 ; Williams, Roy and Gillies, 1976) and never throughout a whole day. 
The purpose of our work was to determine more accurately circadian variations in the abomasal secretions (amounts of juice, enzymes and electrolytes) of the preruminant calf.

\section{Material and methods.}

Animals and diet. - Five Friesian male calves (B, D, E, F and K) were fitted with an abomasal innervated pouch, mainly obtained from the fundic area on the lesser curvature (Guilloteau and Le Calvé, 1977). A catheter allowed permanent collection of the gastric juice. The calves were used between the age of 26 and $145 \mathrm{~d}$. They received a milk-substitute diet based on spray-dried skim-milk powder and tallow which contained $250 \mathrm{~g}$ protein and $190 \mathrm{~g} \mathrm{fat} / \mathrm{kg}$ DM. The concentration of DM at reconstitution increased with the age of the calves from 154 to $182 \mathrm{~g} / \mathrm{kg}$ liquid diet. The milk was bucket-fed in equal quantities twice daily at 8.30 and $15.30 \mathrm{~h}$. The total daily intake was $58 \mathrm{~g} \mathrm{DM} / \mathrm{kg}$ live weight ${ }^{0.75}$.

Collection of gastric juice. - Starting from the morning meal, the gastric juice was collected for $24 \mathrm{~h}$ in a plastic bottle fixed to the catheter and maintained against the abdominal wall of the calf with a harness. Collection was carried out over $12 \mathrm{~d}, 6$ to study electrolyte secretions $\left(\mathrm{Cl}^{-}, \mathrm{H}^{+}, \mathrm{Na}^{+}\right.$and $\left.\mathrm{K}^{+}\right)$and 6 to study enzyme secretions (chymosin and pepsin) (table 1). The juice intended for the study of electrolytes was collected pure. For the study of enzymes, a $2 \mathrm{M}$ piperazine buffer $\mathrm{pH} 6(0.1$ of the mean weight of gastric juice obtained per hour on the previous days) was placed in the bottle before sampling so as to prevent any denaturation of the chymosin and pepsin. The bottle was changed every hour in order to obtain 24 samples. After weighing and $\mathrm{pH}$ determination, the content of the bottle was stored at $-18{ }^{\circ} \mathrm{C}$ until analysis. When the $\mathrm{pH}$ of the juice and buffer mixture was below 5.3 some buffer was added before freezing.

Analysis. - After the juice was thawed, the $\mathrm{pH}$ was measured using a $\mathrm{pH}$ meter (Radiometer pHM $28 \mathrm{D}$ ). The $\mathrm{H}^{+}$ions were estimated by titrating the acidity with $0.1 \mathrm{~N}$ sodium hydroxide in the presence of phenolphtalein $; \mathrm{Na}^{+}$and $\mathrm{K}^{+}$ions were measured by atomic absorption spectrophotometry and $\mathrm{Cl}^{-}$ions by the method of Charpentier-Volhard.

\section{TABLE 1}

Experimental design : number of days of collection.

\begin{tabular}{|c|c|c|}
\hline \multirow{2}{*}{ Calf } & \multicolumn{2}{|c|}{ Study of } \\
\hline & Electrolytes & Enzymes \\
\hline B & 4 & - \\
\hline $\mathrm{D}$ & - & 1 \\
\hline $\mathrm{E}$ & 1 & 3 \\
\hline$F$ & 1 & 1 \\
\hline $\mathrm{K}$ & - & 1 \\
\hline Total & 6 & 6 \\
\hline
\end{tabular}


Juice samples collected for the determination of enzyme activities were thawed, filtrated and dialysed against distillated water and then against piperazine buffer to eliminate impurities. Chymosin and pepsin were thereafter separated by chromatography on a diethyl-amino-ethyl cellulose column, according to the technique of Garnot et al. (1972). Enzyme activities (chymosin and pepsin) were determined by measuring the coagulation time of a solution $(20 \mathrm{~g} / \mathrm{l})$ of $x$-casein, according to the method of Douillard and Ribadeau-Dumas (1970). The results were expressed in $\mathrm{mg}$ of enzymes after standardization of the $x$-casein preparation used.

To reduce the effect of animal age and that of daily and individual variations, the mean hourly amounts collected over $24 \mathrm{~h}$ were calculated from the individual values expressed as a proportion of the total amounts secreted during the day of collection. The values observed for the 24th hour were used as prefeeding data.

\section{Results.}

The health and mean $( \pm$ SE) live weight gain $(954 \pm 91 \mathrm{~g} / \mathrm{d})$ of the animals were satisfactory during the whole experiment.

$\mathrm{pH}$ and quantity of gastric juice. - The hourly $\mathrm{pH}$ variations were rather large, but non-significant (fig. 1). Before the morning meal, the $\mathrm{pH}$ of the gastric juice was close to 1.9. It increased to about 2.35 during the first hour following the morning meal and then decreased to 1.39 during the 4th postprandial hour. The evening meal did not cause the same effect as that of the morning, since the $\mathrm{pH}$ continued to decrease until it reached 1.25 during the 4th hour following the evening meal and then increased until the next morning meal.
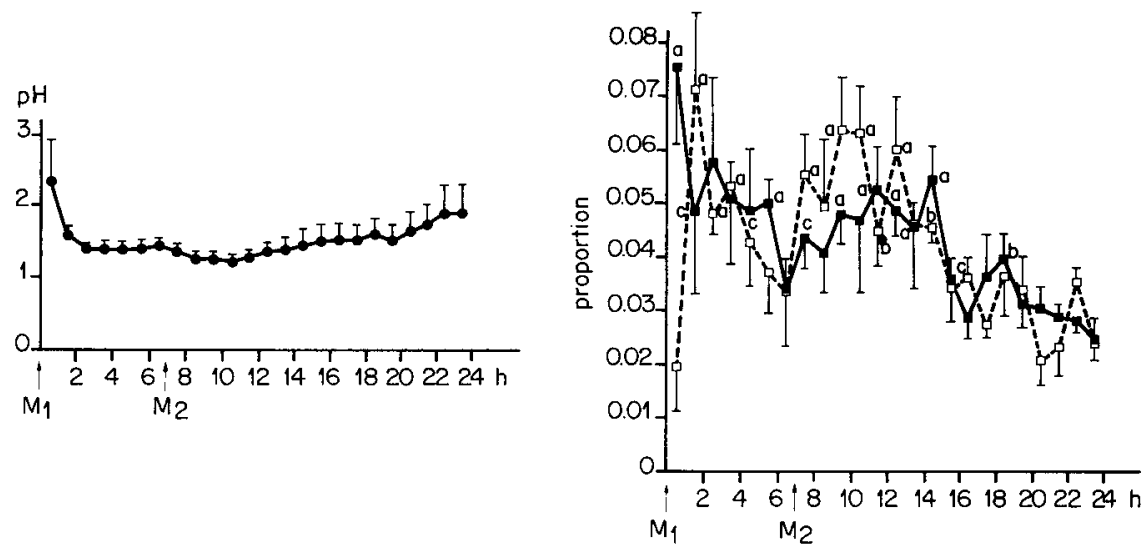

FIG. 1. - Variation in the $\mathrm{pH}$ of the gastric juice secreted during the 24-h cycle (means of $6 \mathrm{~d}$ and $\mathrm{SE}$ ). $\mathrm{M}_{1}$ : morning meal ; $\mathrm{M}_{2}$ : evening meal.

FIG. 2. - Amount of gastric juice secreted during the 24-h cycle (p. 100 of total amounts secreted) (means of $6 \mathrm{~d}$ and SE when the juice was collected for determination of electrolytes $\square$ and enzymes $\square-\square$ ). $M_{1}$ : morning meal ; $M_{2}$ : evening meal ; $a$, b, $c$ : significant differences relative to the 24th hour value $(a: P \leq 0.01 ; b: P \leq 0.02 ; c: P \leq 0.05)$. 
A large increase in the quantity of juice secreted was observed after the morning meal (fig. 2). This increase occurred during the first hour when juice was collected for studying ion secretions, but only during the second hour when it was collected for studying enzyme secretions. During these periods, the secreted quantities were respectively 3.1 and 2.9-fold higher than those recorded during the 24th hour $(P \leq 0.01)$. The quantity secreted then decreased until the 7 th hour. The evening meal caused a less rapid but longer-lasting increase in the quantity secreted. This quantity decreased from the 15th or the 16 th hour of the 24-h cycle.

Electrolytes. - The daily variations in the concentration of the different electrolytes were dissimilar (fig. 3 ). $\mathrm{H}^{+}$concentration generally increased during the first 4 or 5 h following each meal and thereafter decreased. $\mathrm{Na}^{+}$concentration varied in the opposite way. $\mathrm{Cl}^{-}$concentration was maximal within the first hour following the morning meal; it decreased irregularly until the 17th hour and thereafter increased until the end of the circadian cycle. After the first $2 \mathrm{~h}$ following each meal, the $\mathrm{K}^{+}$concentration increased for 2 or $3 \mathrm{~h}$ and thereafter decreased ; it increased again from the 18th to the 24th hour of the 24-h cycle.

The daily mean concentrations of electrolytes varied from 100 to 119 and from 46 to $63 \mathrm{mmol} / \mathrm{l}$, respectively for $\mathrm{Cl}^{-}$and $\mathrm{H}^{+}$in calf $\mathrm{B}(4 \mathrm{~d}$ of measurement) ; the $\mathrm{Na}^{+}$and $\mathrm{K}^{+}$concentrations varied very little (table 2 ). The daily mean concentrations of $\mathrm{Cl}^{-}$and $\mathrm{Na}^{+}$tended to be higher in calves $\mathrm{E}$ and $\mathrm{F}$ than in calf $\mathrm{B}$, whereas that of $\mathrm{H}^{+}$tended to be lower. The sum of the cation concentrations was 1.23 of that of $\mathrm{Cl}^{-}$in calf $\mathrm{B}$, whereas the corresponding value was close to 1.0 in calves $E$ and $F$.

Both meals stimulated the secretions of electrolytes, except for $\mathrm{Na}^{+}$after the evening meal (fig. 4). The increase during the first hour after the morning meal was considerable ; the amounts of $\mathrm{Cl}^{-}, \mathrm{H}^{+}, \mathrm{Na}^{+}$and $\mathrm{K}^{+}$secreted were 3.8, 4.1,
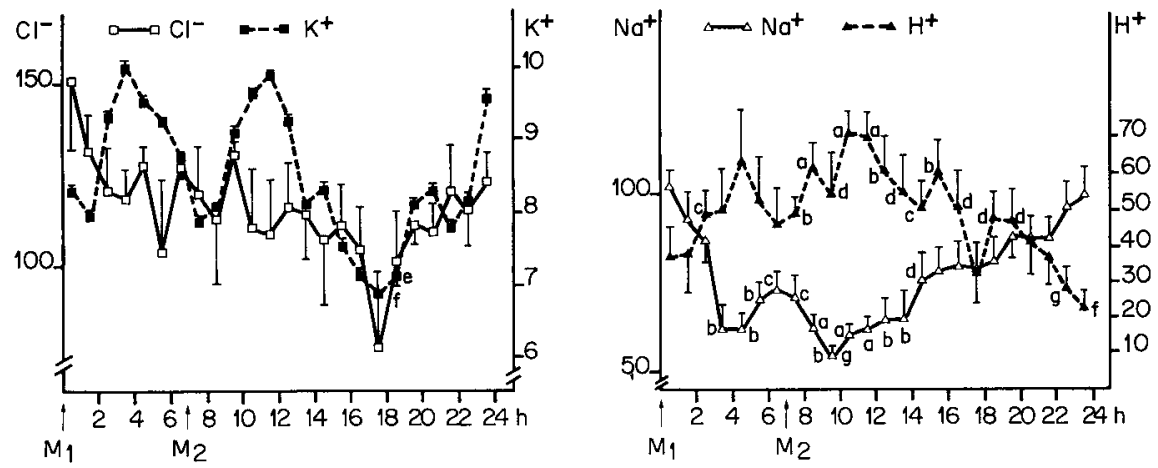

FIG. 3. - Variation in $\mathrm{Cl}^{-}, \mathrm{K}^{+}, \mathrm{Na}^{+}$and $\mathrm{H}^{+}$concentrations (mmol/l) during the 24-h cycle (means of $6 \mathrm{~d}$ and $\mathrm{SE}$ ). $\mathrm{M}_{1}$ : morning meal ; $\mathrm{M}_{2}$ : evening meal. $a, b, c, d, e, f, g$ : significant differences relative to the 24th hour value $\{a: P \leq 0.001 ; b: P \leq 0.01 ; c: P \leq 0.02$; $\mathrm{d}: \mathrm{P} \leq 0.05)$ or to the evening prefeeding value $(\mathrm{e}: \mathrm{P} \leq 0.01 ; \mathrm{f}: \mathrm{P} \leq 0.02 ; \mathrm{g}: \mathrm{P} \leq 0.05)$. 
TABLE 2

Mean composition of gastric juices secreted during the 24-h cycle (mmol/l).

\begin{tabular}{ccccccc}
\hline Calf & Age (d) & $\mathrm{Cl}-$ & $\mathrm{H}^{+}$ & $\mathrm{Na}^{+}$ & $\mathrm{K}^{+}$ & $\begin{array}{c}\text { Sum of } \\
\text { cations }\end{array}$ \\
\hline & 90 & 107 & 63 & 71 & 8 & 142 \\
B & 96 & 102 & 52 & 70 & 8 & 130 \\
& 111 & 100 & 46 & 71 & 8 & 125 \\
& 117 & 119 & 53 & 72 & 8 & 133 \\
\hline $\mathrm{E}$ & 68 & 144 & 42 & 88 & 10 & 140 \\
\hline $\mathrm{F}$ & 62 & 136 & 44 & 81 & 9 & 134 \\
\hline
\end{tabular}
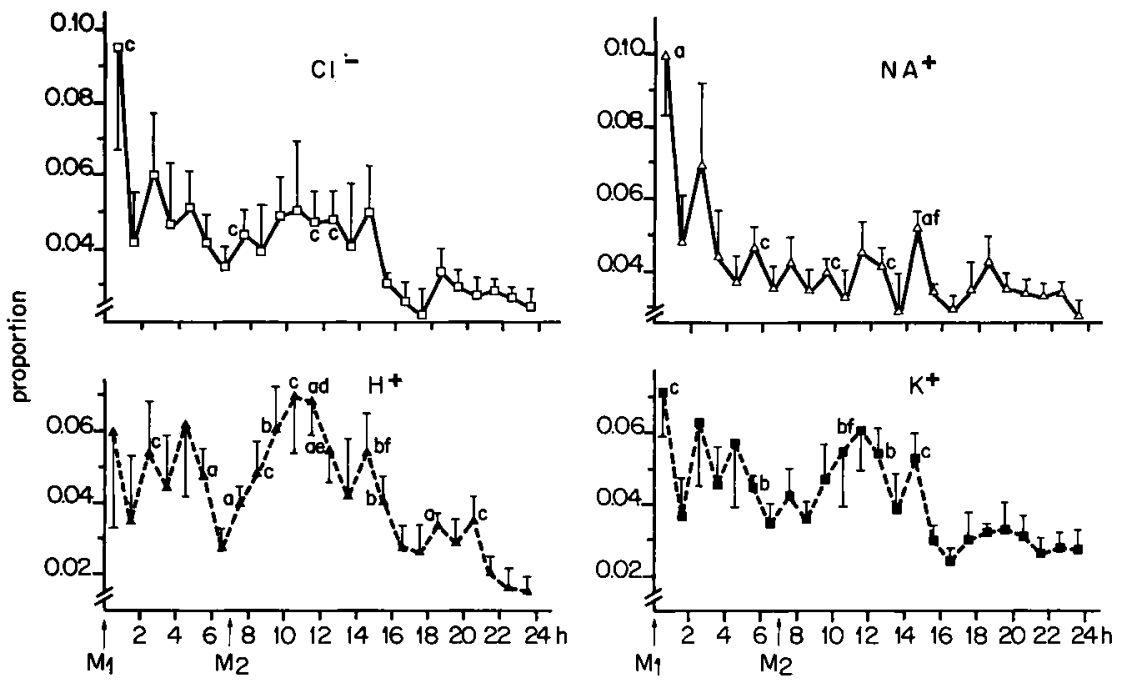

FIG. 4. - Variation in the secretions of $\mathrm{Cl}^{-}, \mathrm{H}^{+}, \mathrm{Na}^{+}$and $\mathrm{K}^{+}$during the 24-h cycle expressed in relation to total secretions during $24 h$ (means of $6 \mathrm{~d}$ and $\mathrm{SE}$ ). $\mathrm{M}_{1}$ : morning meal ; $\mathrm{M}_{2}$ : evening meal. $a, b, c, d, e, f:$ significant differences relative to the 24 th hour value $(a: P \leq 0.01$; $b: P \leq 0.02 ; c: P \leq 0.05)$ or to the evening prefeeding value $(d: P \leq 0.01 ; e: P \leq 0.02$; $f: P \leq 0.05)$.

3.5 and 2.6-fold higher than during the 24th hour ( $P \leq 0.05$, except for $\left.\mathrm{H}^{+}\right)$. The proportions of $\mathrm{H}^{+}$and $\mathrm{K}^{+}$secreted were rather large until the 5th postprandial hour, but those of $\mathrm{Cl}^{-}$and especially of $\mathrm{Na}^{+}$decreased rapidly. The increase observed after the evening meal was slower and continued until the 4th or 5th postprandial hour. The secretions were very low from the 15th or 16th hour of the 24-h cycle, especially for $\mathrm{H}^{+}$ions ; thus, the proportions observed during the 24th hour were $0.025,0.016,0.028$ and 0.027 of the total amounts secreted throughout the day for $\mathrm{Cl}^{-}, \mathrm{H}^{+}, \mathrm{Na}^{+}$and $\mathrm{K}^{+}$, respectively. 
During the first $7 \mathrm{~h}$ following each meal, secretions of juice and electrolytes (except $\mathrm{H}^{+}$) were higher after the morning meal than after the evening meal, but the difference was significant only for $\mathrm{Na}^{+}(P \leq 0.01)$ (table 3$)$. The proportions of electrolytes secreted during the $7 \mathrm{~h}$ after the morning meal were very close to that of gastric juice. This was also true for $\mathrm{Cl}^{-}$and $\mathrm{K}^{+}$during the first $7 \mathrm{~h}$ following the evening meal, but not for $\mathrm{Na}^{+}$and $\mathrm{H}^{+}$; the proportion of $\mathrm{Na}^{+}$. collected was lower $(P \leq 0.02)$ and that of $H^{+}$higher $(P \leq 0.05)$ than that of juice.

Enzymes. - Chymosin and pepsin concentrations ranged from 78 to 203 and from 30 to $87 \mathrm{mg} / \mathrm{l}$, respectively. These concentrations were not significantly higher during the first hour following the morning meal than during the 24th hour ; however, from the 3rd to the 7th hour, an increase in the concentration of chymosin was observed ( $\mathrm{P} \leq 0.05$ ). The level of pepsin varied only little until the evening meal. This latter meal was followed by a significant decrease in the enzyme concentrations. The concentrations thereafter increased until the $21 \mathrm{st}$ hour and varied only little until the end of the 24-h cycle (fig. 5). The chymosin/pepsin ratio did not significantly change throughout the day ; individual variability was very marked, as shown by large standard errors.

During the first $2 \mathrm{~h}$ after the morning meal, the proportions of enzymes secreted were higher $(P \leq 0.05)$ than during the 24th hour; thus, chymosin and pepsin secretions during the first postprandial hour were 2.4 and 2.1-fold higher. They decreased $(P \leq 0.05\rangle$ during the 3rd hour and thereafter they slightly increased until the next meal ; this increase was less marked for pepsin than for chymosin. During the $2 \mathrm{~h}$ surrounding the evening meal, secretions were high, after which they decreased irregularly until the end of the circadian cycle. However, the minimal values remained a little higher than those for $\mathrm{H}^{+}$ions : the

TABLE 3

Comparison of quantities secreted (proportion of total secretions throughout the day) during the first $7 \mathrm{~h}$ following the meals (means and SE).

\begin{tabular}{llll}
\hline & \multirow{2}{*}{$\begin{array}{c}\text { Number of days } \\
\text { of } \\
\text { collection }\end{array}$} & \multicolumn{2}{c}{ 7-h period after the : } \\
\cline { 3 - 4 } & & \multicolumn{1}{c}{ morning meal } & \multicolumn{1}{c}{ evening meal } \\
\hline Juice & & $0.355(0.030)$ & $0.310(0.017) \mathrm{df}$ \\
$\mathrm{H}^{+}$ & 6 & $0.330(0.064)$ & $0.380(0.026) \mathrm{f}$ \\
$\mathrm{Cl}^{-}$ & & $0.373(0.044)$ & $0.321(0.030)$ \\
$\mathrm{Na}^{+}$ & & $0.377(0.020) \mathrm{c}$ & $0.263(0.016) \mathrm{cd}$ \\
$\mathrm{K}^{+}$ & & $0.361(0.041)$ & $0.331(0.023)$ \\
\hline Juice & 6 & $0.306(0.022) \mathrm{eg}$ & $0.382(0.022) \mathrm{abg}$ \\
Chymosin & & $0.357(0.020) \mathrm{e}$ & $0.311(0.021) \mathrm{a}$ \\
Pepsin & & $0.337(0.027)$ & $0.299(0.024) \mathrm{b}$ \\
\hline
\end{tabular}

Values followed by the same letter are significantly different at $P \leq 0.01(a, b, c), P \leq 0.02$ (d) or $\mathbf{P} \leq 0.05(e, f, g)$. 

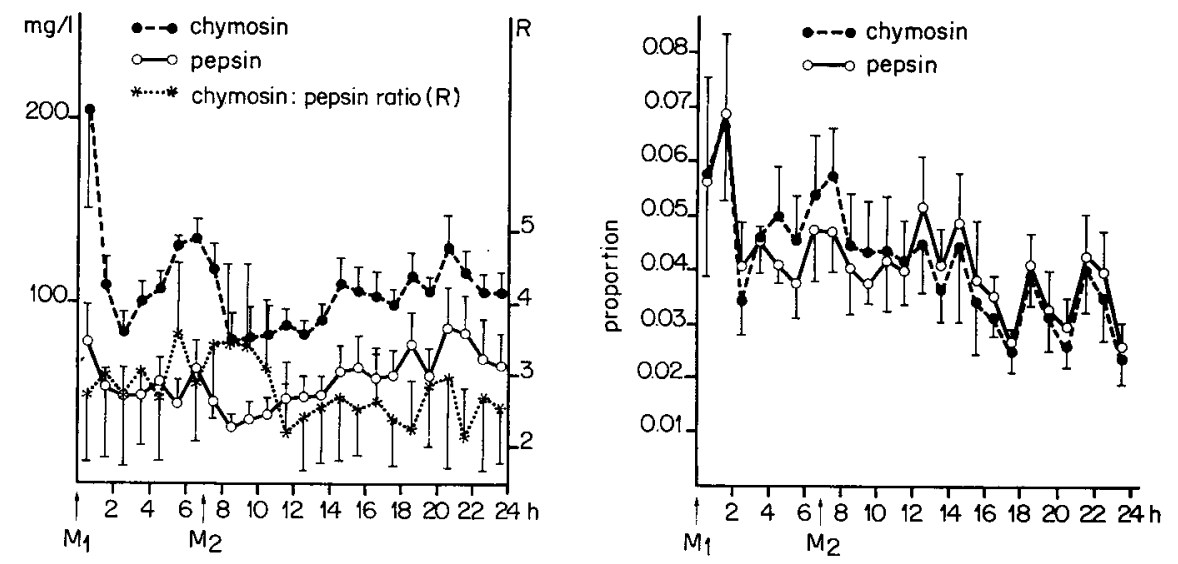

FIG. 5. - Variation in the enzyme concentration ( $\mathrm{mg} / \mathrm{l})$, in the chymosin/pepsin ratio (R) and in the amounts of enzymes secreted per hour (proportion of total amounts secreted during $24 \mathrm{~h}$ ) during the 24-h cycle (means of $6 \mathrm{~d}$ and $\mathrm{SE}$ ). $\mathrm{M}_{1}$ : morning meal ; $\mathrm{M}_{2}$ : evening meal. $a, b, c, d, e, f$ : significant differences relative to the 24th hour value $(a: P \leq 0.01 ; b: P \leq 0.02 ; c: P \leq 0.05)$ or to the evening prefeeding value $(d: P \leq 0.01 ; e: P \leq 0.02 ; f: P \leq 0.05)$

proportions secreted during the 24th hour were $0.024,0.026$ and 0.016 , for chymosin, pepsin and $\mathrm{H}^{+}$ions, respectively.

During the first $7 \mathrm{~h}$ following the morning meal, the proportions of chymosin and pepsin secreted hourly represented about 0.051 and 0.048 , respectively, of the total amounts secreted during the day (table 3 ) ; the corresponding values for the first $7 \mathrm{~h}$ after the evening meal were 0.044 and 0.043 for chymosin and pepsin, respectively ; these values did not differ significantly from those after the morning meal.

\section{Discussion.}

In our experimental conditions, the secretion from the abomasal pouch of the preruminant calf was continuous during the 24-h cycle. However, we did not study true circadian rhythm because we did not use unfed animals. The quantities of gastric juice secreted increased after each meal as reported by other authors. Our results are in agreement with those of Ash (1964) and Rusev, Petrov and Bocheva (1971) who observed a rise in secretion starting 15-30 min after the meal and reaching a maximum 30-90 min later. However, Williams, Roy and Gillies (1976) reported that the maximum only occurred within 3-4 $\mathrm{h}$ after a meal. These discrepancies among authors are probably due to different techniques for estimating secretions and for feeding the calves and to individual and daily variations. The latter might explain the differences in secretions between the 2 sets of collection days.

Among the electrolytes, only $\mathrm{Cl}^{-}, \mathrm{H}^{+}, \mathrm{K}^{+}$and $\mathrm{Na}^{+}$ions were assayed. The gastric juice contains large quantities of these electrolytes which represent the main components involved in osmotic pressure, the other components together 
only supplying less than 10 mOsm (Davenport, 1968). In calves $E$ and $F$, the sum of the assayed cation concentrations $\left(\mathrm{H}^{+}, \mathrm{K}^{+}\right.$and $\left.\mathrm{Na}^{+}\right)$was similar to that of $\mathrm{Cl}^{-}$, but the sum was much higher than that of $\mathrm{Cl}^{-}$in calf $\mathrm{B}$. The gastric pouch of calf $B$ might have overlapped a little of the antral area ; the difference observed for calf $B$ could be due to a higher secretion of bicarbonate ions which were not assayed, leading to an underestimation of the anions (Davenport, 1968).

The patterns of $\mathrm{pH}$ and total $\mathrm{H}^{+}$output in relation with feeding agreed with published results (Ash, 1964 ; Hill, Noakes and Lowe, 1970 ; Williams, Roy and Gillies, 1976). The variation of $\mathrm{pH}$ in the abomasal pouch was not representative of changes in the $\mathrm{pH}$ of the abomasal contents. The $\mathrm{pH}$ of the contents is much higher after the meal because of the dilution induced by the intake of milk and its buffering capacity (Hill, Noakes and Lowe, 1970; Guilloteau et al., 1975 and 1979) : it ranges around 5 after the first $0.5 \mathrm{~h}$, then decreases progressively, but $7 \mathrm{~h}$ after a meal it is still 3.5. The decrease in the $\mathrm{pH}$ of the gastric juice collected after the morning meal could account for the large increase in the concentration of $\mathrm{H}^{+}$ions together with a concomitant decrease in the concentration of $\mathrm{Na}^{+}$ions which was not compensated by an increase in the concentration of $\mathrm{K}^{+}$ions. Since the meals were not at equal intervals, the differences between their effects were probably due partly to the fact that there were less food residues left in the abomasum at the morning meal than at the evening meal.

Since $\mathrm{Na}^{+}$ions are produced partly by diffusion through the mucosa in exchange with $\mathrm{H}^{+}$ions (Davenport, 1968), it is not surprising that the concentration of $\mathrm{Na}^{+}$varied inversely with that of $\mathrm{H}^{+} \mathrm{lr}=-0.819$; $\mathrm{P} \leq 0.001$ ). On the other hand, the concentration and output of $\mathrm{K}^{+}$varied directly with those of $\mathrm{H}^{+}(\mathrm{r}=0.891 ; \mathrm{P} \leq 0.001$, for the output $)$; likewise, when acid secretion is stimulated by histamin, there is a concomitant increase in the concentration of $\mathrm{K}^{+}$ions (Davenport, 1968). Variations in the secretion of $\mathrm{H}^{+}$ ions were determined more by changes in the volume of the juice secreted $\langle r=0.752 ; \mathrm{P} \leq 0.001)$ than by the concentration of $\mathrm{H}^{+}$ions $(r=0.532$; $P \leq 0.01$ ). This is in keeping with the findings of Hollander (1952) who showed that acid concentration may be independent of the output of gastric juice. The concentration of $\mathrm{Cl}^{-}$ions in the gastric juice was unrelated to the concentration of each cation separately $\left(r=0.082 ; 0.182\right.$ and 0.354 respectively for $\mathrm{H}^{+}, \mathrm{Na}^{+}$ and $\mathrm{K}^{+} ; \mathrm{NS}$ ) but is was correlated with the total concentration of cations ( $r=0.498 ; P \leq 0.02$ ).

Enzyme secretions increased during the first $2 \mathrm{~h}$ after the morning meal or during the first hour after the evening meal. This is in agreement with other observations made in the calf which showed that the outputs of enzymes were maximal 10-20 min (Grosskopf, 1959 ; Ash, 1964) or $1 \mathrm{~h}$ (Williams, Roy and Gillies, 1976) after a meal and thereafter decreased during the next $5 \mathrm{~h}$ (Williams, Roy and Gillies, 1976). In our experiment, it would probably have been better to divide the first postprandial hour into shorter periods so as to determine more accurately the moment of maximal secretion. The variation in total chymosin and pepsin secretions mainly depended on the amount of juice produced $(r=0.511$ and 0.497 , respectively; $P \leq 0.01$ ), but not on the concentrations of these 
enzymes ( $r=0.285$ and 0.094 , respectively; NS). On the contrary, Williams, Roy and Gillies (1976) reported that protease secretion was mainly determined by its concentration. In addition, we observed strong correlations between the concentrations of chymosin and pepsin as well as between the amounts secreted ( $r=0.667$ and 0.884 , respectively ; $P \leq 0.001$ ).

A comparison between the $\mathrm{pH}$ curve of digesta leaving the abomasum after a milk meal (Guilloteau et al., 1975 and 1979) and the curves of enzyme secretions showed that the trends were similar. Immediately after a meal, the $\mathrm{pH}$ was high (about 5) so that the enzymes secreted in large quantities could exert their coagulating activity. The $\mathrm{pH}$ thereafter decreased progressively towards values more favourable to the overall proteolytic activity of pepsin (Henschel, 1973 ; Roy and Stobo, 1975).

The phenomena observed may partly be related with the regulatory mechanisms involved. Many gastrointestinal hormones are liable to favour secretions of acid (gastrin and CCK-PZ) or enzymes (gastrin and secretin) (Walsh, Debas and Grossman, 1974 ; Desbuquois, 1978 ; Hacki, 1980 ; McLeay and Bell, 1981 ) ; others seem to have an inhibitory effect on the secretion of acid (secretin, somatostatin, vasoactive intestinal peptide and glucagon) and enzymes (somatostatin and VIP) (Villar, Fender and Rayford, 1976 ; Arnold and Lankish, 1980 ; Hacki, 1980 ; McLeay and Bell, 1981). However, only a few data are available about the postprandial changes in the production of gastrin and glucagon in the preruminant calf (Bloom, Edwards and Hardy, 1978 ; Accary et al., 1983 ; Guilloteau et al., unpublished data).

The psychic stimuli associated with the morning meal (sight, hearing, smell, taste and ingestion) (Siebers, 1978), as well as the distension of the abomasum, act via the parasympathic nervous system or via histamin, leading to a rapid increase in the secretion of enzymes and electrolytes, if the preruminant calf behaves like a monogastric animal (Davenport, 1968), During the first 2 postprandial hours, the effects of gastrin is questionable. Bloom, Edwards and Hardy (1978) observed an increase in the concentration of gastrin in the blood during that period. However, according to Guilloteau et al., (unpublished data), this period corresponds to the moment when the level of gastrineamia is one of the lowest of the whole 24-h cycle in calves reared in conditions similar to those applied to our experimental animals fitted with a gastric pouch. The blood concentration of glucagon varies only a little during that $2-\mathrm{h}$ period (Bloom, Edwards and Hardy, 1978).

From the 2 nd to the 6 th postprandial hour, the secretion of acid and protease was favoured by an increase in the concentration of gastrin in blood (Guilloteau et al., unpublished data). A return to the original secretions that began during the 7th hour, at least for acid secretion, was stopped by the ingestion of the second meal. The evening meal seemed to be followed by a more marked increase in the secretion of acid than of enzymes. From the 9th hour after the evening meal, i.e. the 17th hour of the circadian cycle, the gastric secretions, especially those of water and electrolytes, were very low although the blood concentration of gastrin did not change very much. This might be explained by the inhibition exerted by other gastrointestinal hormones like somatostatin, vasoactive intestinal peptide 
and secretin whose blood concentrations may be particularly high at that time due to the fact that an acid chyme $(\mathrm{pH}$ close to 2, according to Guilloteau et al., 1975 and 1979) has entered the duodenum. Increase in the blood level of secretin might explain why the enzyme secretions decreased less than the acid secretion.

In conclusion, variations in the abomasal secretions of the preruminant calf during the circadian cycle are closely related with the ingestion of meals. These secretions are controlled by the interaction of a series of complex nervous and hormonal mechanisms which are not yet perfectly known. A study of the secretions in starved calves would permit a better distinction between the influence of the meals and that of a possible circadian rhythm.

Recu en novembre 1982. Accepté en mai 1983.

Acknowledgement. - We are grateful to Alice Daifuku and Kirsten Rérat for the translation of the French manuscript and to P. Martin for the standardization of $x$ casein.

Résumé. Evolution nycthémérale des sécrétions abomasales chez le veau préruminant.

Le but de ce travail est d'étudier l'évolution nycthémérale des sécrétions abomasales (quantités de suc, d'enzymes et d'électrolytes) chez le veau préruminant. Pour cela, le suc gastrique est collecté heure par heure chez 5 veaux porteurs d'une poche abomasale innervée et recevant 2 repas de lait par jour, séparés par un intervalle de $7 \mathrm{~h}$. Au total, 6 journées de mesures sont réalisées pour les enzymes (chymosine et pepsine) et 6 pour les électrolytes $\left(\mathrm{Cl}^{-}, \mathrm{H}^{+}, \mathrm{Na}^{+}\right.$et $\left.\mathrm{K}^{+}\right)$.

Les sécrétions gastriques sont continues mais sont soumises à des variations qui sont nettement en relation avec l'ingestion des repas. Le premier repas provoque une augmentation considérable des quantités d'électrolytes et d'enzymes sécrétés : les valeurs de la première heure postprandiale sont respectivement $3,8-4,1-3,5-2,6-2,4$ et 2,1 fois plus fortes que celles de la vingt-quatrième heure pour les ions $\mathrm{Cl}^{-}, \mathrm{H}^{+}, \mathrm{Na}^{+}$et $\mathrm{K}^{+}$, la chymosine et la pepsine. L'influence du second repas' est moins nette sur les sécrétions d'ions $\mathrm{Na}^{+}$et $\mathrm{Cl}^{-}$et celles d'enzymes; elle est également plus tardive pour tous les électrolytes. Les variations des quantités horaires sécrétées sont plus fortes pour les ions $\mathrm{H}^{+}$que pour les enzymes: ainsi, les rapports entre les quantités maximale et minimale observées au cours du nycthémère sont de 4,6 pour les ions $\mathrm{H}^{+}$et de 2,8 pour la chymosine.

\section{References}

ACCARY J. P., GUilloteau P., TOULleC R., CHAYVIALle J. A., DUBRASOUet M., REINBERG A., 1983. Patterns of circadian and ultradian rhythms in plasma gastrin of preruminant calves during fast and after feeding. XV/th int. Conf., Int. Soc. Chronobiol., Dublin.

ARNOLD R., LANKISH P. G., 1980. Somatostatin and the gastrointestinal tract. Clinics Gastroenterol., 9, 733-753.

ASH R. W., 1964. Abomasal secretion and emptying in suckled calves. J. Physiol., 172, 425-438. 
BLOOM S. R., EDWARDS A. V., HARDY R. M., 1978. The role of the autonomic nervous system in the control of pancreatic endocrine responses to milk ingestion in the calf. $J$. Physiol., 280, 37-53.

DAVENPORT H. W., 1968. Physiologie de /'appareil digestif. Masson, Paris, 247 pp.

DAVICCO M. J., 1978. Régulation du pancréas exocrine du jeune veau. Th. Doct. $3^{e}$ cycle, Clermont.Ferrand, $101 \mathrm{pp}$.

DESBUQUOIS B., 1978. Les hormones gastrointestinales, 309-355. In BEAULIEU E. E., Hormones. Hermann, Paris.

DOUILLARD R., RIBADEAU-DUMAS B., 1970. Détermination avec la caséine $\kappa$ de l'activité protéolytigue de la présure, de la pepsine de porc et des pepsines bovines. Bull. Soc. Chim. biol., 52, 1429-1445.

GARNOT P., THAPON J. L., MATHIEU C. M., MAUBOIS J. L., RIBADEAU-DUMAS B., 1972. Determination of rennin and bovine pepsins in commercial rennets and abomasal juices. $J$. Dairy Sci., 55, 1641-1650.

GROSSKOPF J. F. W., 1959. Some factors affecting the secretion of abomasal juice in young dairy calves. Onderstepoort vet. Res., 28, 133-141.

GUILLOTEAU P., LE CALVÉ J. L., 1977. Technique de réalisation d'une poche abomasale chez le veau en vue de l'obtention du suc gastrique pur. Ann. Biol. anim. Bioch. Biophys., 17, 1047-1060.

guilloteau P., paruelle J. L., toullec R., Mathieu C. M., 1975. Utilisation des protéines par le veau préruminant. III. Influence du remplacement des protéines du lait par celles du poisson sur la vidange stomacale. Ann. Zootech., 24, 243-253.

GUILLOTEAU P., TOULLEC R., PATUREAU-MIRAND P., PRUGNAUD J., 1981. Importance of the abomasum in the preruminant calf. Reprod. Nutr. Dévelop., 21, 885-899.

GUILLOTEAU P., TOULLEC R., SAUVANT P., PARUELLE J. L., 1979. Utilisation des protéines par le veau préruminant à l'engrais. VII. Influence du remplacement des protéines du lait par celles du soja ou de la féverole sur l'évacuation gastrique. Ann. Zootech., 28, 1-17.

HÄCKI W. H., 1980. Secretin. Clinics Gastroenterol., 9, 609-632.

HENSCHEL M. J., 1973. Comparison of the development of proteolytic activity in the abomasum of the preruminant calf with that in the stomach of the young rabbit and guinea pig. $B r . J$. Nutr., 30, 285-296.

HILL K. J., NOAKES D. E., LOWE R. A., 1970. Gastric digestive physiology of the calf and piglet, 169-179. In PHILIPSON A. T., Physiology of digestion and metabolism in the ruminant. Oriel Press, Newcastle upon Tyne.

HOLLANDER F., 1952. Gastric secretion of electrolytes. Fed. Proc., 11, 706-714.

MCLEAY L. M., BELL F. R., 1981. Effect of cholecystokinin, secretin, glucagon and insulin on gastric emptying and acid secretion in the calf. Am. J. vet. Res., 41, 1590-1594.

ROY J. H. B., STOBO I. J. F., 1975. Nutrition of the preruminant calf, 30-48. In McDONALD I. W., WARNER A. C. I., Digestion and metabolism in the ruminant, Univ. New-England Publ. Unit, Armidale.

RUSEV V., PETROV A., BOCHEVA E., 1971. Particularities of rennet secretion in nursing calves in connection with the manner of feeding in milk temperature. Nautsh Ind. Zootech. Fac., 22, $145-156$.

SIEBERS R., 1978. Characteristics of gastric secretion in suckling calves. Acta physiol. pol., 29. 581-588.

VILLAR H. V., FENDER H. R., RAYFORD P. L., 1976. Suppression of gastrin release and gastric secretion by gastric inhibitory peptide (GIP) and vasoactive intestinal peptide (VIP). Ann. Surg., 184, 97-102.

WALSH J. H., DEBAS H. T., GROSSMAN M. I., 1974. Pure human big gastrin : immunochemical properties, disappearance half time and acid stimulating action in dogs. J. clin. Invest., 54, 477-485.

WILLIAMS V. J., ROY J. H. B., GILLIES C. H., 1976. Milk substitute diet composition and abomasal secretion in the calf. Br. J. Nutr., 36, 317-335. 